V. Yaloveha, D. Hlavcheva, A. Podorozhniak

National Technical University "Kharkiv Polytechnic Institute”, Kharkiv, Ukraine

\title{
USAGE OF CONVOLUTIONAL NEURAL NETWORK FOR MULTISPECTRAL IMAGE PROCESSING APPLIED TO THE PROBLEM OF DETECTING FIRE HAZARDOUS FOREST AREAS
}

\begin{abstract}
Neural networks are intensively developed and used in all spheres of human activity in the modern world. Their use to determine the fire hazardous forest areas can begin to solve the problem of preventing wildfires. In recent years, wildfires have acquired enormous proportions. Wildfires are difficult to control and, if they occur, require a large amount of resources to eliminate them. The paper is devoted to solve the problem of identifying fire hazardous forest areas. The Camp Fire (California, USA) areas are considered. The purpose of the paper is to research the possibility of using convolutional neural networks for the detection fire hazardous forest areas using multispectral images obtained from Landsat 8 . The tasks of research are finding the territories where the largest fires occurred in recent time; analyzing economic and ecologic losses from wildfires; receiving and processing multispectral images of wildfire areas from satellite Landsat 8; calculation of spectral indices (NDVI, NDWI, PSRI); developing convolutional neural network and analyzing results. The object of the research is the process of detecting fire hazardous forest areas using convolutional neural network. The subject of the research is the process of recognition multispectral images using deep learning neural network. The scientific novelty of the research is the recognition method of multispectral images by using convolutional neural network has been improved. The theory of deep learning neural networks, the theory of recognition multispectral images and mathematical statistics methods are used. The spectral indices for allocating the object under research (green vegetation, humidity, dry carbon) were calculated. It is obtained that the classification accuracy for a convolutional neural network on the test data is $94.27 \%$.

Keywords : deep learning; convolutional neural networks; multispectral images; spectral indices; fire hazardous forest areas.
\end{abstract}

\section{Introduction}

An artificial neural network (ANN) is an information-processing paradigm that is inspired by the way biological nervous systems [1]. An ANN is configured for a specific application, such as data classification or recognition. The first artificial neuron was produced in 1943 by the neurophysiologist Warren McCulloch and the logician Walter Pits [2].

Artificial neural networks are used in different spheres for making decisions. In medicine neural networks are recognizing diseases from various scans. Neural network application would fit into financial analysis. There is a strong potential for using neural networks for database mining. Neural networks have been applied successfully to problems like derivative securities pricing, exchange rate forecasting and etc.

In the research, convolutional neural networks are used for detecting fire hazardous forest areas. Fire problems are increasing. Many millions of hectares have burnt in the last three decades, affecting health and livelihoods for tens of millions of people costing billions of dollars [3].

One of the largest wildfire happened in California (USA) in July 2018. It was called Mendocino Complex. The total area of the fire was almost 460 thousand acres. In less than six months in this state, a wildfire called the Camp Fire took place again. The total area of the Camp Fire was over 150 thousand acres [4].

In Fig. 1 the total largest forest areas (from 1960 to 2017) is presented [5]. The largest forest areas were burned in 2015 and 2017 (more than 10 million acres). In five years, with the total largest fire area, there was no one year less than 2006, which suggests that the problem of forest fires causes more losses than in the XX century.
According to the USA statistics, [6] compared to the 1980s, now, the number of burned acres have increased almost twice, while the number of wildfires has decreased. The losses from a large number of forest fires are human lives and natural resources. The fires cause economic costs to overcome and eliminate them (Fig. 2).

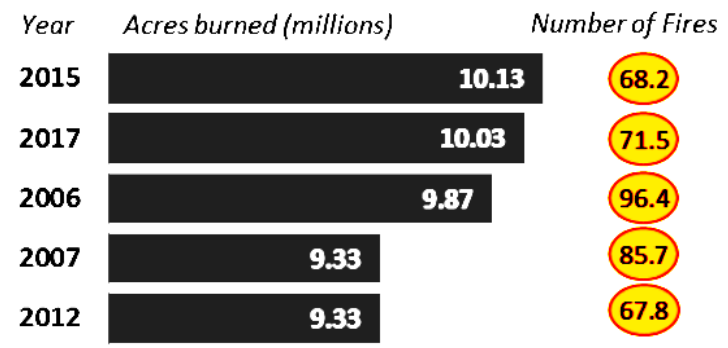

Fig. 1. The Total Largest Fire Area in Millions of Acres, 1960 - 2017, USA

The purpose of the paper is to research the possibility of using convolutional neural networks for the detection of fire hazardous forest areas using multispectral images of the Earth remote sensing.

In the paper, the convolutional neural network is used to solve the problem of detecting fire hazardous forest areas. The multispectral images from the Landsat 8 will be received [7]. The spectral indices that are able to detect arid vegetation, moisture content and carbon are calculated. Such an approach can lead to solve the problem of preventing wildfires.

\section{Multispectral Images and Spectral Indices}

Earth remote sensing it is an approach, which use data from satellites for receiving actual information about Earth surface. Earth remote sensing data provided in form of multispectral images. 
(2017 \$ millions)

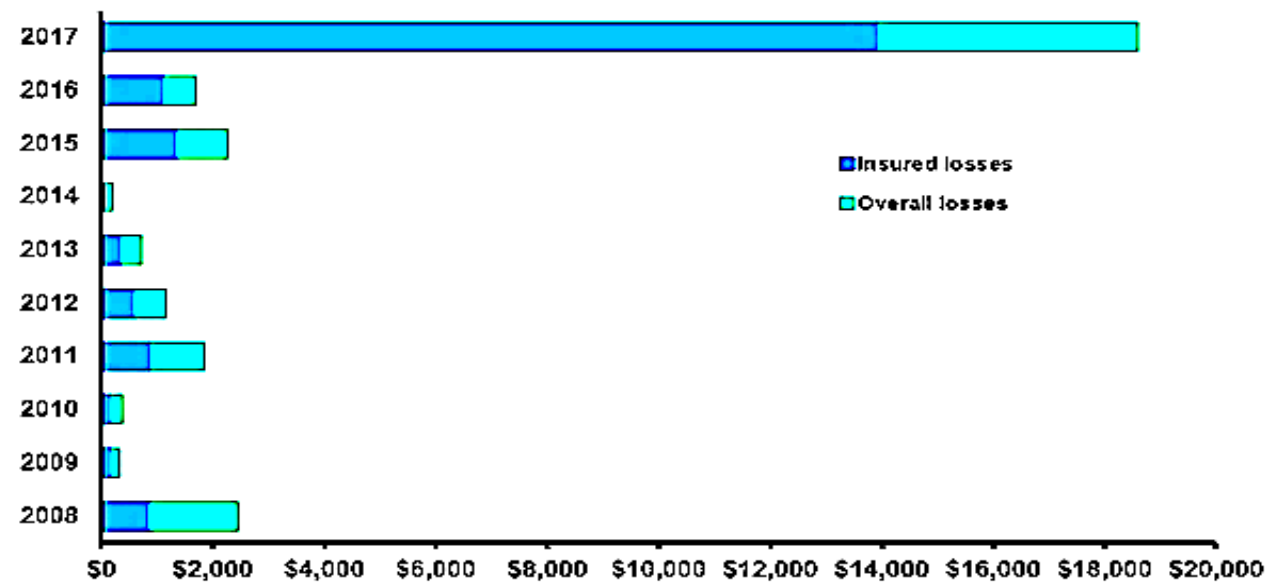

Fig. 2. Wildfire Losses in the USA, 2008-2017

The relevant data of the Earth remote sensing are obtained from the satellite Landsat 8 [8].

The mission of the Landsat Project is to provide repetitive acquisition of moderate-resolution multispectral data of the Earth's surface on a global basis. Landsat represents the only source of global, calibrated, moderate spatial resolution measurements of the Earth's surface that are preserved in a national archive and freely available to the public.

The data from the Landsat spacecraft constitute the longest record of the Earth's continental surfaces as seen from space [7].

As input data, the Camp Fire area of October 7, 2018 was taken. The fire began on 8th of November, 2018. The coordinates of Camp Fire are 39 $50^{\prime} 51^{\prime \prime} \mathrm{N}$, $121^{\circ} 23^{\prime} 42^{\prime \prime} \mathrm{W}$ [9].

To work with spectral data, index images are used. An image is constructed corresponding to the index value in each pixel based on a combination of brightness values in certain channels. This can allocate the object under research.

Index PSRI [10] is used to find the total amount of "dry" carbon presenting by lignin and cellulose. Such carbon in large quantities is present in wood, dead or dry plant tissues.

The index is calculated by next equation:

$$
I_{P S R I}=\frac{\rho_{R E D}-\rho_{G R E E N}}{\rho_{N I R}},
$$

where $\rho_{\text {GREEN }}$ - reflectance in the green band, $\rho_{R E D}$ - reflectance in the red spectral band, $\rho_{N I R}$ - reflectance in the near infrared spectral band.

NDVI is the vegetation index. It is used to detect green vegetation in multispectral images.

The index is calculated by next formula [11]:

$$
I_{N D V I}=\frac{\rho_{N I R}-\rho_{R E D}}{\rho_{N I R}+\rho_{R E D}} .
$$

NDWI [12] estimates the water content. Healthy vegetation, which grows faster and more resistant to fire, has high humidity.

The index is calculated by next equtation:

$$
I_{N D W I}=\frac{\rho_{N I R}-\rho_{S W I R}}{\rho_{N I R}+\rho_{S W I R}},
$$

where $\rho_{S W I R}$ - reflectance in the short wave infrared band.

The Camp Fire area after calculation and merging of three indecies as RGB channels (red channel is responsible for PSRI, green - for NDVI, blue - for NDWI) is presented in Fig. 3.

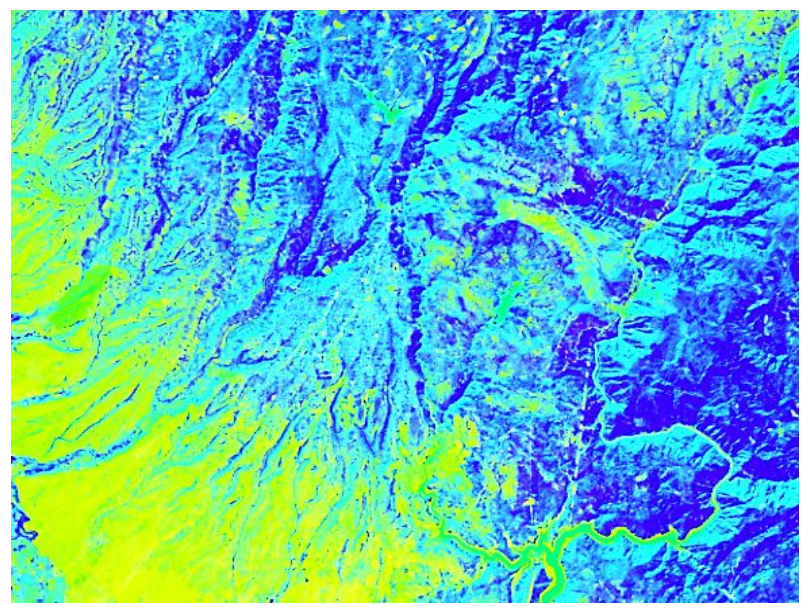

Fig. 3. The Merged Index Image of The Camp Fire Area

Merged image will be used by convolutional neural network for detecting fire hazardous forest areas.

\section{Convolutional Neural Networks}

The Deep Learning concept was introduced in 2006. It is as a new field of research within machine learning. Deep Learning concept was first known as hierarchical learning at the [13]. Deep Learning considers nonlinear processing in multiple layers and supervised or unsupervised learning [14]. Deep Learning can be understood as a method to improve results and optimize processing times in several computing processes [15]. Recent researches have applied deep learning as the main tool for digital image processing [16].

Convolutional neural network (ConvNet) was developed by Yann LeCun in 1988. Productivity of 
image recognizing by convolutional neural networks [17] caused their using by the largest technological companies (Google, Facebook, Microsoft, IBM and etc). Convolutional neural networks were created on the basis of "simple cells" in human brain. Such cells were discovered in 1960s by Torsten Nils Wiesel and David Habel [18].

Convolution is a mathematic operation (kind of integral conversion) on two functions $f(x)$ and $g(x)$ that produces a third function.

Convolution preserves the spatial relationship between pixels by learning image features using small squares of input data.

The simple architecture of ConvNet for image recognizing by $z$ classes can be divided into two parts: a sequence of convolutional or alternating pooling layers and several fully-connected layers. On the output layer of the neural network, the neuron activation function is used.

The activation function can be, for instance, ReLU [19]. In the process of training the neural network, a problem of overfitting could appear. To solve this problem the Dropout layer could be added in the convolutional neural network [20-22].

\section{Implementation}

The total amount of prepared images were 40,000. Half with fire hazardous area and half with area without fire hazardous. All images were separated into three sets: training (28,000 images), validation (6,000 images) and test (6,000 images) data (Fig. 4).

The size of each image is $(32 \times 32)$ pixels in three RGB channels. Sample images for both groups are shown in Fig. 5.
As a programming environment, we used Spyder IDE and Python 3.6 as a programming language. The frameworks were Tensorflow 1.6 and Keras 2.2.4.

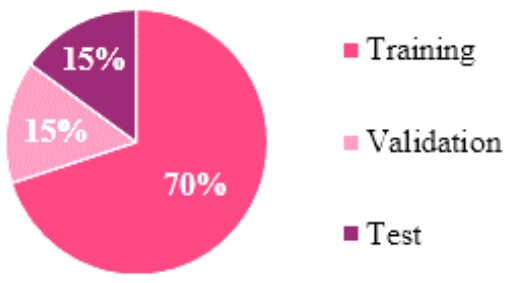

Fig. 4. Training, validation and test datasets

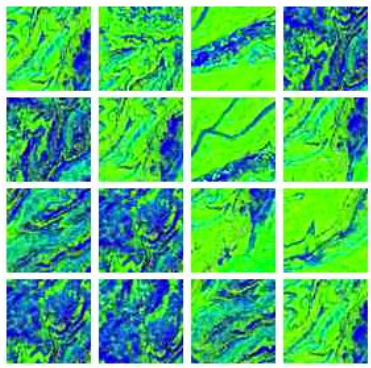

a

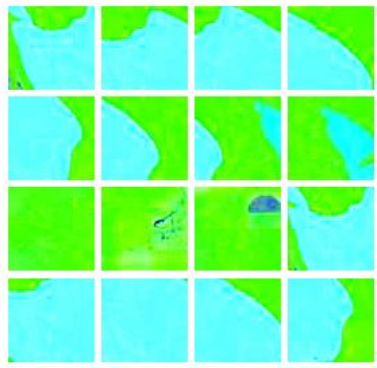

b
Fig. 5. Examples of images for neural network: a) fire hazardous area; b) area without fire hazardous

For training, we used an ASUS laptop. The laptop has $16 \mathrm{~Gb}$ of RAM, one Nvidia GeForce 940MX GPU and an Intel Core 17 extreme 7th generation CPU (up to $3.5 \mathrm{GHz})$.

Convolutional neural network architecture is presented in Fig. 6. The total amount of parameters in convolutional neural network is 45,153.

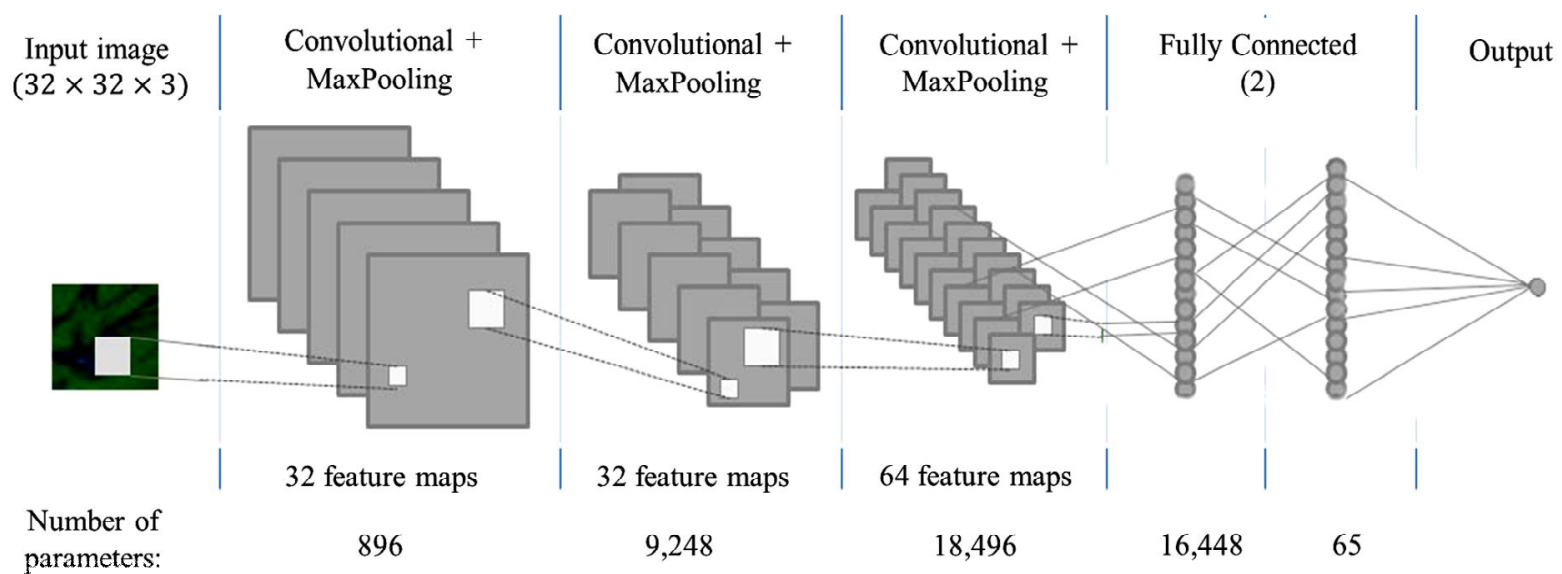

Fig. 6. Convolutional neural network architecture

\section{Results and Conclusions}

The convolutional neural network was trained during 50 epochs. The total training time was 60 minutes. The graphs of the accuracy classification and loss on the number of epochs for the training and validation data are shown in Fig. 7, 8.

The accuracy of classification on test data for convolutional neural network is $94.27 \%$. The maximum value of classification accuracy is $99 \%$ on training (38th epoch) and validation (32nd epoch) data. The minimum value is $95 \%$ on training dataset and $92 \%$ on validation dataset.

The maximum and minimum loss values are $14 \%$ and $0.2 \%$ on training data. For validation dataset, these values are $24 \%$ (43rd epoch) and 3\% (27th epoch).

The scientific and practical problem of detecting fire hazardous forest areas by using convolutional neural network applied to the Camp Fire is solved in the paper. 
The spectral indices were calculated using multispectral images from Landsat 8. It is obtained that convolutional neural networks can effectively classify objects belonging to two classes from our dataset. Such approach can begin to solve the problem of preventing wildfires.

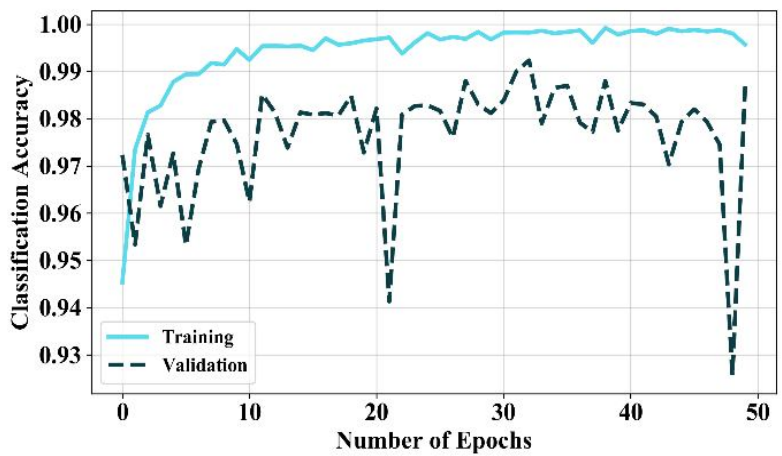

Fig. 7. The classification accuracy dependence on the number of epochs on training and validation data

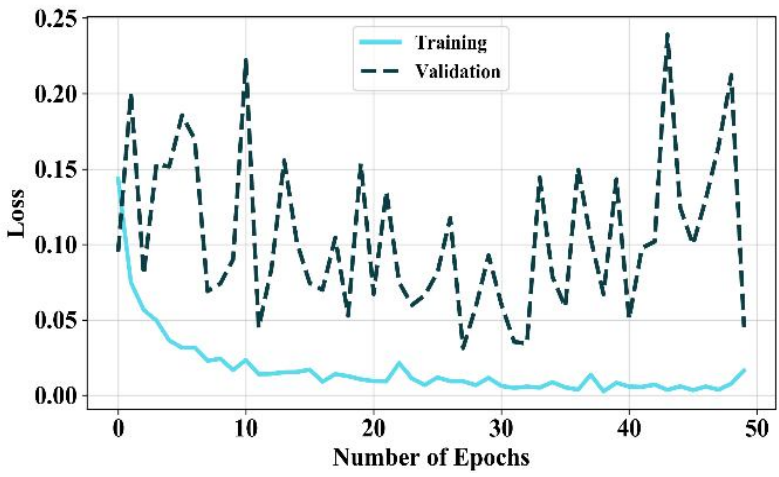

Fig. 8. The loss dependence on the number of epochs on training and validation data

\section{REFERENCES}

1. Nahar, K. (2012), "Artificial neural network", COMPUSOFT, An international journal of advanced computer technology, Vol. 1, No. 2, pp. 25-27, available at: https://ijact.in/index.php/ijact/article/view/421/366 (last accessed December 9, 2018).

2. McCulloch, W. S. and Pitts, W. (1943), "A logical calculus of the ideas immanent in nervous activity", The bulletin of mathematical biophysics, Vol. 5, No. 5, pp. 115-133, available at: www.fao.org/docrep/article/wfc/xii/0829-b3.htm (last accessed December 12, 2018).

3. Moore, P., Hardesty, J., Kelleher, S., Maginnis, S. and Myers, R. (2003), "Forests and wildfires: fixing the future by avoiding the past", XII World Forestry Congress, Quebec, Canada, available at: https://doi.org/10.1007/BF02478259 (last accessed December 11, 2018).

4. The Departmant of Forestry and Fire Protection of California: Top 20 Largest California Wildfires (2017), available at: https://www.fire.ca.gov/communications/downloads/fact sheets/Top20 Acres.pdf (last accessed December 15, 2018).

5. Hoover, K. (2018), Wildfire Statistics Congressional Research Service, available at: https://fas.org/sgp/crs/misc/IF10244.pdf (last accessed December 10, 2018).

6. Insurance Information Institute: Facts \& Statistics: Wildfires: Wildfire Losses In The United States (2017), available at: https://www.iii.org/fact-statistic/facts-statistics-wildfires (last accessed December 9, 2018).

7. Department of the Interior. U.S. Geological Survey. LANDSAT 8 (L8) DATA USERS HANDBOOK, (2018), available at: https://landsat.usgs.gov/sites/default/files/documents/LSDS-1574 L8 Data Users Handbook.pdf (last accessed December 10, 2018).

8. U.S. GeologicalSurvey (2018), available at: https://earthexplorer.usgs.gov (last accessed December 10, 2018).

9. The Departmant of Forestry and Fire Protection of California: Public Information Map, (2018), available at: http://cdfdata.fire.ca.gov/pub/cdf/images/incidentfile2277_4287.pdf (last accessed December 11, 2018).

10. Merzlyak, M. N., Gitelson, A. A., Chivkunova, O. B. and Rakitin, V. Y. (1999) 'Non-destructive optical detection of pigment changes during leaf senescence and fruit ripening', Physiologia plantarum, Vol. 106, pp. 135-141, available at: https://doi.org/10.1034/j.1399-3054.1999.106119.x (last accessed December 12, 2018).

11. Bardysh, B. and Burshtynskaya, Kh. (2014), "Using vegetation indices to identify objects on the earth surface", Modern achievements in geodetic science and production, No. 2, pp. 82-88, available at: http://nbuv.gov.ua/UJRN/sdgn 2014221 (last accessed December 9, 2018).

12. Jackson, T. J., Chen, D., Cosh, M., Li, F., Anderson, M., Walthall, C., Doriaswamy, P. and Hunt, E. R. (2004), "Vegetation water content mapping using Landsat data derived normalized difference water index for corn and soybeans", Remote Sensing of Environment, Vol. 92, No. 4, pp. 475-482, available at: https://doi.org/10.1016/j.rse.2003.10.021 (last accessed December 11, 2018)

13. Mosavi, A. and Varkonyi-Koczy, A. R. (2017), "Integration of machine learning and optimization for robot learning", Recent Global Research and Education: Technological Challenges: Springer, pp. 349-355, available at: https://doi.org/10.1007/9783-319-46490-9 47 (last accessed December 11, 2018).

14. Bengio, Y. (2009), "Learning deep architectures for AI", Foundations and trends in Machine Learning, Vol. 2, No. 1, pp. 1127, available at: https://doi.org/10.1561/2200000006 (last accessed December 10, 2018).

15. Vargas, R., Mosavi, A. and Ruiz, R. (2018), "Deep learning: a review", Advances in Intelligent Systems and Computing, available at: https://doi.org/10.20944/preprints201810.0218.v1 (last accessed December 12, 2018).

16. Lee, T. S. and Mumford, D. (2003), "Hierarchical Bayesian inference in the visual cortex", Journal of the Optical Society of America A, Vol. 20, No. 7, pp. 1434-1448, available at: https://doi.org/10.1364/JOSAA.20.001434 (last accessed December $10,2018)$.

17. LeCun, Y., Bengio, Y. and Hinton, G. (2015), "Deep learning", Nature, No. 521 (7553), pp. 436-444, available at: https://doi.org/10.1038/nature14539 (last accessed December 9, 2018). 
18. Hubel, D. H. and Wiesel, T. N. (1962), "Receptive fields, binocular interaction and functional architecture in the cat's visual cortex", The Journal of physiology, Vol. 160, No. 1, pp. 106-154, available at:

https://doi.org/10.1113/jphysiol.1962.sp006837 (last accessed December 11, 2018).

19. Hlavcheva, D. and Yaloveha, V. (2018), "Capsule neural networks", Control, Navigation and Communication Systems, Vol. 5, No. 51, pp. 132-135, available at: https://doi.org/10.26906/SUNZ.2018.5.132 (last accessed December 12, 2018).

20. Liubchenko, N., Podorozhniak, A. and Bondarchuk, V. (2017), "Neural network method of intellectual processing of multispectral images", Advanced information System, Vol. 1, No. 2, pp. 39-44, available at: https://doi.org/10.20998/25229052.2017.2.07 (last accessed December 9, 2018).

21. Podorozhniak, A., Lubchenko, N., Balenko, O. and Zhuikov, D. (2018), "Neural network approach for multispectral image processing". Advanced Trends in Radioelecrtronics, Telecommunications and Computer Engineering (TCSET-2018), 14th International Conference on: IEEE, pp. 978-981, available at: http://dx.doi.org/10.1109/TCSET.2018.8336357 (last accessed December 10, 2018).

22. Hlavcheva, D. and Yaloveha, V. (2018), "CapsNet versus ConvNet", Computer sciences, control and artificial intelligence, 5th International Conference, Kharkiv, Ukraine, pp. 22-23, available at: http://pim.net.ua/arch f/tez iyii 2018.pdf (last accessed December 10, 2018).

Нрадійшла (received) 30.01.2019

Використання згорткової нейронної мережі для обробки мультиспектральних зображень, застосованої до проблеми виявлення пожежонебезпечних лісових територій

В. А. Яловега, Д. М. Главчева, А. О. Подорожняк

У сучасному світі нейронні мережі інтенсивно розвиваються і використовуються в усіх сферах людської діяльності. Їх застосування для визначення пожежонебезпечності лісових територій може розпочати вирішення проблеми попередження лісових пожеж. Лісові пожежі важко контролюються та, у разі виникнення, вимагають великої кількості ресурсів для їх усунення. Робота присвячена вирішенню задачі визначення пожежонебезпечності лісових територій. Розглядається територія пожежі «Camp Fire», що сталася у Каліфорнії (США). Метою роботи $є$ дослідження можливості застосування згорткових нейронних мереж для визначення пожежонебезпечності лісових територій на основі мультиспектральних зображень, отриманих з супутника Landsat 8. Поставлена мета передбачає вирішення таких завдань: огляд територій, на яких відбулися наймасштабніші лісові пожежі за останній час, аналіз економічних та екологічних збитків від лісових пожеж; отримання та обробка мультиспектральних зображень території пожежі 3 супутника Landsat 8; розрахунок спектральних індексів (NDVI, NDWI, PSRI); реалізація згорткової нейронної мережі та аналіз результатів роботи. Об'єктом дослідження є процес визначення пожежонебезпечних лісових територій 3 використанням згорткової нейронної мережі. Предметом дослідження є процес розпізнавання мультиспектральних зображень 3 використанням нейронних мереж глибокого навчання. Наукова новизна полягає в удосконаленні методу розпізнавання мультиспектральних зображень за рахунок використання згорткових нейронних мереж. Методами досліджень $\epsilon$ теорія нейронних мереж глибокого навчання, теорія розпізнавання мультиспектральних зображень, методи математичної статистики. Обчислено спектральні індекси для виділення характеристик досліджуваної території (зеленої рослинності, кількості вологи, сухого вуглецю). Отримана точність класифікації для згорткової нейронної мережі на тестовій вибірці склала $94.27 \%$.

Ключові слов а: глибоке навчання; згорткові нейронні мережі; мультиспектральні зображення; спектральні індекси; пожежонебезпечні лісові території.

\section{Использование сверточной нейронной сети для обработки мультиспектральных изображений применимо к проблеме обнаружения пожароопасных лесных территорий}

\section{В. А. Яловега, Д. М. Главчева, А. А. Подорожняк}

В современном мире нейронные сети интенсивно развиваются и используются во всех сферах человеческой деятельности. Их применение для определения пожароопасности лесных территорий может начать решение проблемы предупреждения лесных пожаров. Лесные пожары трудно контролируются и, в случае возникновения, требуют большого количества ресурсов для их устранения. Работа посвящена решению задачи определения пожароопасности лесных территорий. Рассматривается территория пожара «Саmp Fire», которая произошла в Калифорнии (США). Целью работы является исследование возможности применения сверточных нейронных сетей для определения пожароопасности лесных территорий на основе мультиспектральных изображений, полученных со спутника Landsat 8. Поставленная цель предполагает решение таких задач: рассмотрение территорий, на которых произошли масштабные лесные пожары за последнее время, анализ экономических и экологических убытков от лесных пожаров; получение и обработка мультиспектральных изображений территории пожара со спутника Landsat 8; расчет спектральных индексов (NDVI, NDWI, PSRI); реализация сверточной нейронной сети и анализ результатов работы. Объектом исследования является процесс определения пожароопасных лесных территорий с использованием сверточной нейронной сети. Предметом исследования является процесс распознавания мультиспектральных изображений с использованием нейронных сетей глубокого обучения. Научная новизна заключается в усовершенствовании метода распознавания мультиспектральных изображений за счет использования сверточных нейронных сетей. Методами исследований является теория нейронных сетей глубокого обучения, теория распознавания мультиспектральных изображений, методы математической статистики. Вычислены спектральные индексы для выделения характеристик исследуемой территории (зеленой растительности, количества влаги, сухого углерода). Точность классификации для сверточной нейронной сети на тестовой выборке составила $94.27 \%$.

Ключевые слова: глубокое обучение; сверточные нейронные сети; мультиспектральные изображения; спектральные индексы; пожароопасные лесные территории. 